San Jose State University

SJSU ScholarWorks

Faculty Publications, Biological Sciences

Biological Sciences

$1-1-2011$

\title{
Lichens of Callahan Mine, a copper and zinc-enriched Superfund site in Brooksville, Maine, U.S.A.
}

N Rajakaruna

San Jose State University, nrajakaruna@gmail.com

T B. Harris

Department of Plant, Soil, and Insect Sciences, University of Massachusetts

S Clayden

New Brunswick Museum

A Dibble

School of Biology and Ecology, University of Maine

F S. Olday

College of the Atlantic

Follow this and additional works at: https://scholarworks.sjsu.edu/biol_pub

Part of the Plant Sciences Commons

\section{Recommended Citation}

N Rajakaruna, T B. Harris, S Clayden, A Dibble, and F S. Olday. "Lichens of Callahan Mine, a copper and zinc-enriched Superfund site in Brooksville, Maine, U.S.A." Rhodora (2011): 1-31. https://doi.org/10.3119/ 10-03.1

This Article is brought to you for free and open access by the Biological Sciences at SJSU ScholarWorks. It has been accepted for inclusion in Faculty Publications, Biological Sciences by an authorized administrator of SJSU ScholarWorks. For more information, please contact scholarworks@sjsu.edu. 
RHODORA, Vol. 113, No. 953, pp. 1-31, 2011

(c) Copyright 2011 by the New England Botanical Club

\title{
LICHENS OF THE CALLAHAN MINE, A COPPER- AND ZINC-ENRICHED SUPERFUND SITE IN BROOKSVILLE, MAINE, U.S.A.
}

\author{
Nishanta RaJAKARUnA \\ Department of Biological Sciences, San José State University, \\ One Washington Square, San José, CA 95192-0100 \\ Current Address: College of the Atlantic, 105 Eden Street, \\ Bar Harbor, ME 04609 \\ e-mail:nrajakaruna@gmail.com
}

\section{TANNER B. HARRIS}

Department of Plant, Soil, and Insect Sciences, University of Massachusetts, Fernald Hall, 270 Stockbridge Road, Amherst, MA 01003

\section{Stephen R. Clayden}

New Brunswick Museum, 277 Douglas Avenue, Saint John, NB, Canada E2K 1E5

\section{Alison C. DibBle}

School of Biology and Ecology, University of Maine, 100 Murray Hall, Orono, ME 04469

\section{Fred C. Olday}

College of the Atlantic, 105 Eden Street, Bar Harbor, ME 04609

ABSTRACT. Metal-enriched habitats often harbor physiologically distinct biotas able to tolerate and accumulate toxic metals. Plants and lichens that accumulate metals have served as effective indicators of ecosystem pollution. Whereas the diversity of metal-tolerant lichens has been well documented globally, the literature of metal-tolerant lichen communities for eastern North America is limited. We examined the lichen flora of the Callahan Mine, a Cu-, $\mathrm{Pb}$-, and $\mathrm{Zn}$-enriched superfund site in Brooksville, Hancock County, Maine, U.S.A. Through collections along transects across metal-contaminated areas of the mine, we documented 76 species of lichens and related fungi. Fifty species were saxicolous, 26 were terricolous. Forty-three species were macrolichens, 31 were microlichens. Although no globally rare or declining species were encountered at the mine, two regionally rare or declining species, Stereocaulon tomentosum and Leptogium imbricatum, were found. The species found at the Callahan Mine were mostly ecological generalists frequenting disturbed habitats. Two extensively studied Cu-tolerant lichens, Acarospora smaragdula and Lecanora polytropa, and other known $\mathrm{Cd}-, \mathrm{Cu}-, \mathrm{Pb}-$, and $\mathrm{Zn}$-tolerant taxa, were found at the site. 
Key Words: biomonitoring, conservation, edaphic ecology, endemism, environmental pollution, extremophiles, lichen-metal relations, remediation, serpentine

Recently there has been much interest in edaphically extreme environments as hotspots for plant diversity (Whiting et al. 2004). Metal-enriched sites have also attracted attention as refuges for rare and/or physiologically distinct species or ecotypes (Rajakaruna and Boyd 2008). Such edaphically restricted species have served as models for testing key ecological and evolutionary theories (Harrison and Rajakaruna 2011). Metal-tolerant and hyperaccumulating plants are also potentially useful for phytoremediation, a rapidly developing green technology that employs plants to clean up metal-contaminated sites (Chaney et al. 2007; Marques et al. 2009; Pilon-Smits and Freeman 2006).

Lichens are a dominant component of the biodiversity of many metal-contaminated sites. The ability of lichens to tolerate and accumulate high levels of potentially toxic heavy metals has led to their widespread use as biomonitors of atmospheric (Conti and Cecchetti 2001) and substrate-level metal concentrations (Aznar et al. 2008), including their potential use in biogeochemical prospecting for heavy metals such as $\mathrm{Cu}, \mathrm{Fe}, \mathrm{Pb}$, and $\mathrm{Zn}$ (Easton 1994; Purvis and Halls 1996) and assessing airborne Hg (Garty 2001) and radionuclides (Kirchner and Daillant 2002). Lichens lack a protective cuticle and roots; they obtain their nutrients mainly through atmospheric inputs or direct contact with mineral particles (Nash 1989; Purvis 1996; Richardson 1995). Thus, lichens are able to accumulate minerals, including toxic heavy metals, at levels exceeding their metabolic requirements (Bačkor and Loppi 2009). Lichens tolerate excessive amounts of heavy metals extracellularly via sequestration as metal oxalates, lichen acid-metal complexes, melanin pigments, and organic phosphates (Purvis and PawlikSkowrońska 2008) and intracellularly by chelation and detoxification via phytochelatin synthesis (Bačkor and Loppi 2009). Some lichens are able to accumulate considerable amounts of heavy metals including $\mathrm{Cd}, \mathrm{Cu}, \mathrm{Cr}, \mathrm{Fe}, \mathrm{Hg}, \mathrm{Ni}, \mathrm{Pb}, \mathrm{U}$, and $\mathrm{Zn}$ (Garty 1993; McLean et al. 1998; Purvis et al. 2004, 2011). Notable in this regard are Acarospora rugulosa Körb. (16\% Cu on a dry mass basis; Chisholm et al. 1987), Lecidea lactea Flörke ex Schaer. (5\% Cu on a dry mass basis; Purvis 1984), and Lecanora polytropa (Ehrh.) Rabenh. $(1.3 \% \mathrm{Cu}$ on a dry mass basis; Pawlik-Skowrońska et al. 
2006). Additional species of these genera and those in Aspicilia A. Massal., Porpidia Körber, Rhizocarpon Ramond ex DC., Stereocaulon Hoffm., and Tremolecia M. Choisy dominate metal-enriched substrates worldwide (Bačkor and Loppi 2009; Nash 1989). Many metal-tolerant species exhibit a high degree of specificity for metalenriched substrates and show disjunct distributions corresponding to the availability of such substrates worldwide (Easton 1994; Nash 1989).

Metallophytes, including lichens, and their habitats are of special conservation interest (Rajakaruna and Boyd 2008; Whiting et al. 2004). Metal-enriched sites are quickly being converted to industrial or recreational settings or being remediated via intrusive technological and chemical means to remove or immobilize the metal contaminants. Although metal-enriched sites such as mine spoils are toxic and adversely impact ecosystem health, they often support unusual life forms, including rich lichen floras harboring physiologically distinct, rare, and endangered species (Purvis 1993; Purvis and James 1985). For example, the 'copper lichen' (Lecidea inops Th. Fr.) is a Red Data Book species included in Schedule 8 of the U.K. Wildlife and Countryside Act of 1981 (Church et al. 1996).

Although lichens of metal-enriched habitats have attracted much attention globally (Purvis and Halls 1996; Purvis and PawlikSkowrońska 2008), there has been little recent effort to document lichen communities of metal-enriched habitats in northeastern North America (Rajakaruna et al. 2009a). A recent study by Harris et al. (2007) documented a unique lichen flora for a small, metalenriched serpentine outcrop on Little Deer Isle, Maine. This suggests that other metal-enriched habitats in the region may also harbor rare or physiologically distinct species.

Maine has a rich history of metal mining (Lepage et al. 1991). Such activity has left a few large areas contaminated with $\mathrm{Cu}, \mathrm{Fe}$, $\mathrm{Pb}, \mathrm{Ag}$, and $\mathrm{Zn}$ along the coastal volcanic belt from the Blue Hill Peninsula to Lubec. Probably the most famous operation was the open-pit Harborside Mine between Brooksville and Cape Rosier (now the Callahan Mine) which produced 800,000 tons of copper and zinc ore from 1968 to 1972 . The ore contained approximately $17 \%$ zinc, $7 \%$ copper, and 5\% lead (Environmental Protection Agency 2003). The largest producer in the region was the Black Hawk mine (now Kerr-American Mine) in nearby Blue Hill, an underground mine that produced an estimated 1,000,000 tons of zinc-copper-lead ore between 1972 and 1977. Although heavy 
metals have not been mined in Maine since 1977, previous mining activity, including those at the Callahan and Kerr-American mines, has led to several vast, metal-enriched habitats along coastal Maine. The biodiversity of such habitats is largely unknown, although unpublished baseline environmental assessments have been conducted by the Environmental Protection Agency [EPA; website (http://www.epa.gov/region1/superfund/sites/callahan), EPA Regional Office, Boston, MA.] Currently there is no mining activity beyond gravel extraction, but there are additional significant deposits of metals in Maine, including the Ledge Ridge deposit in Parmachenee, a sulfide deposit with several million tons of $\mathrm{Cu}, \mathrm{Zn}$, $\mathrm{Pb}$; the Bald Mountain deposit west of Portage, a $\mathrm{Cu}-\mathrm{Zn}$ sulfide deposit with an estimated 36 million tons of ore; the Mount Chase $\mathrm{Cu}-\mathrm{Pb}-\mathrm{Ag}-\mathrm{Zn}$ deposit near Patten; and the Alder Pond deposit, with an estimated 1.5-3 million tons of high grade $\mathrm{Cu}-\mathrm{Zn}$ ore underground. The habitats overlying these deposits are potential sites for the discovery of unusual metallophytes, including rare and metal-indicating lichens.

This study examines the saxicolous (rock inhabiting) and terricolous (soil inhabiting) lichen flora of the Callahan Mine. We present the lichen flora with relevant ecological and geochemical data from the site, and discuss the ecological significance and distribution of regionally rare species and species with known tolerance to heavy metals such as $\mathrm{Cd}, \mathrm{Cu}, \mathrm{Pb}$, and $\mathrm{Zn}$.

\section{MATERIALS AND METHODS}

The Callahan Mine is a former intertidal open-pit mine located near the Holbrook Island Sanctuary in Brooksville, Hancock County, Maine $\left(44^{\circ} 20^{\prime} \mathrm{N}, 68^{\circ} 48^{\prime} \mathrm{W}\right.$; WGS 84; Figure 1). The 61 ha site underwent intermittent mining operations from 1880-1964 and was heavily mined from 1964-1972. A $98 \mathrm{~m}$ deep pit was excavated adjacent to and under Goose Pond, a tidal estuary dammed at both ends to permit mining. The pit was flooded in 1972, returning the estuary to its original (dammed) level. In 2002, the Callahan Mine was listed as a Superfund Site (Environmental Protection Agency 2002) due to elevated levels of inorganic and organic contaminants, and a remediation plan was put into action in September 2009.

The site consists of a flooded tidal pit, Goose Pond, an artificial wetland on sediments dredged from the pit, a tailings pond, an ore pad, and three waste rock piles in addition to several dilapidated 


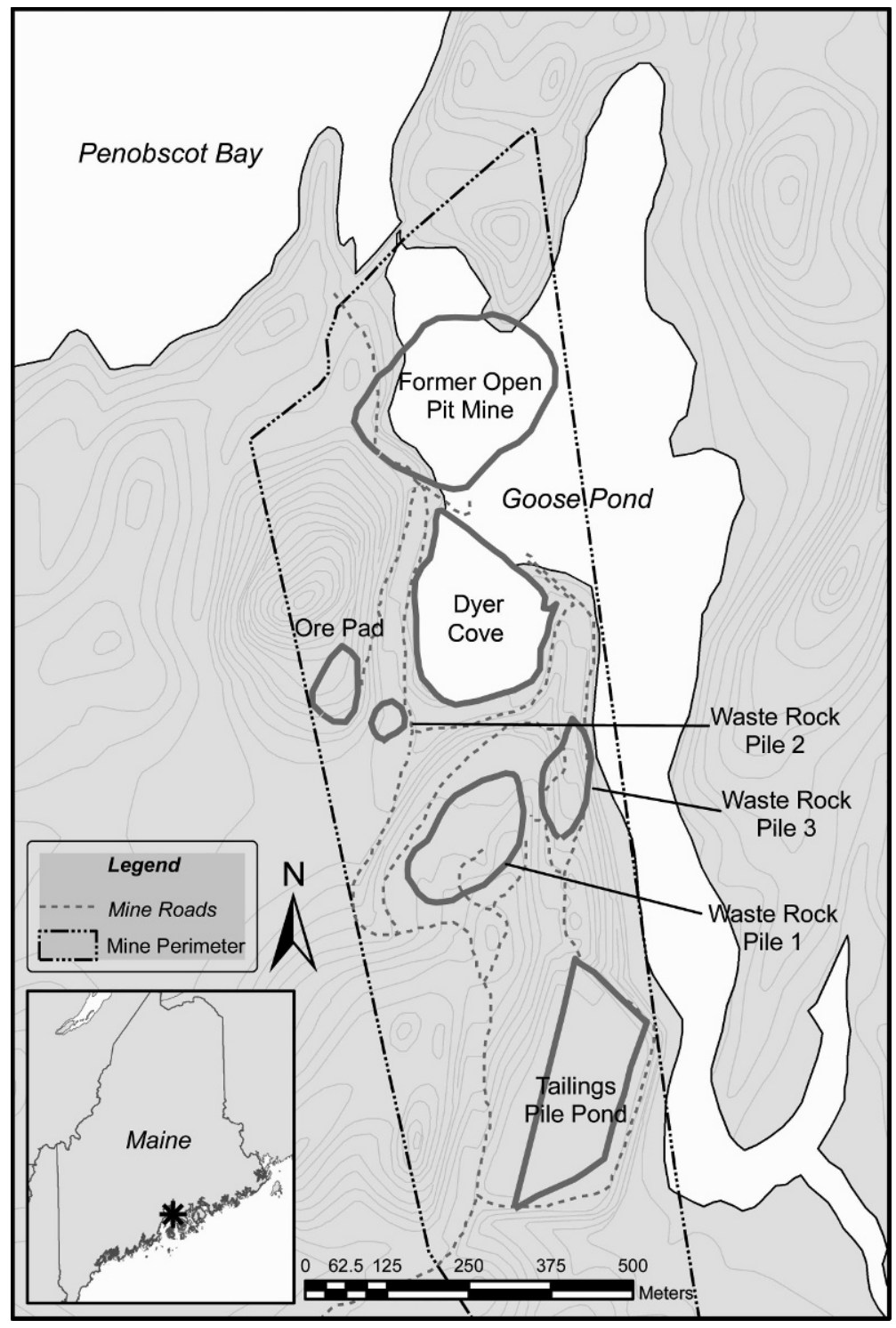

Figure 1. Map of the Callahan Mine, Brooksville, Maine, highlighting locations where lichens were sampled. Credit: Jose Perez-Orozco. 
structures. Since 1972, vegetation has regenerated along the edges of Goose Pond and along roads, most commonly with Betula populifolia Marsh. (Betulaceae), Comptonia peregrina (L.) J.M. Coult. (Myricaceae), Juniperus communis L. (Cupressaceae), Morella pensylvanica (Mirb.) Kartesz (Myricaceae), Populus balsamifera L. (Salicaceae), and Thuja occidentalis L. (Cupressaceae). Substrates throughout the site range from boulders and small rocks to pebbles, coarse gravel, sand, fine silt, and wood. The underlying rock occurs as lenses of mixed sulfides of $\mathrm{Cu}, \mathrm{Fe}, \mathrm{Pb}$, and $\mathrm{Zn}$, replacing highly sheared and altered agglomerates (Environmental Protection Agency 2003). The bedrock of the Callahan Mine and the adjacent portion of the mainland is composed of a series of volcanics - rhyolitic and andesitic flows, agglomerates, and pyroclastics - folded with a northeasterly regional strike and intruded by sills and dikes of diorite. The volcanics are collectively called the Castine formation and tentatively assigned to the early or middle Paleozoic (Environmental Protection Agency 2003). At the mine itself, a large pegmatite intrusion was exploited for mineral extraction. The mined shoreline along Goose Pond is steep and rocky - ranging from coarse gravel to large boulders. Waste Rock Pile 1, the largest of the three waste rock piles, is composed of large stone, gravel, and soil and is highly exposed due to its height and central position within the mine complex (Figure 1).

Lichen samples were collected: (1) along the mined portion of Goose Pond (GP), $10 \mathrm{~m}$ above the low tide line, with 22 sampling points at $20 \mathrm{~m}$ intervals along a single transect starting at $44^{\circ} 21.026^{\prime} \mathrm{N}, 68^{\circ} 48.461^{\prime} \mathrm{W}$ and ending at $44^{\circ} 21.997^{\prime} \mathrm{N}$, $68^{\circ} 48.429^{\prime} \mathrm{W}$; and (2) at the central Waste Rock Pile 1 (WR), along three $\mathrm{N}-\mathrm{S}$ transects $50 \mathrm{~m}$ apart, with a total of 11 sampling points at $40 \mathrm{~m}$ intervals along each transect. Starting and ending coordinates for the three transects were as follows: transect 1, $44^{\circ} 20.788^{\prime} \mathrm{N}, 68^{\circ} 48.463^{\prime} \mathrm{W}$ to $44^{\circ} 20.729^{\prime} \mathrm{N}, 68^{\circ} 48.433^{\prime} \mathrm{W}$; transect $2,44^{\circ} 20.794^{\prime} \mathrm{N}, 68^{\circ} 48.409^{\prime} \mathrm{W}$ to $44^{\circ} 20.729^{\prime} \mathrm{N}, 68^{\circ} 48.418^{\prime} \mathrm{W}$; transect $3,44^{\circ} 20.767^{\prime} \mathrm{N}, 68^{\circ} 48.488^{\prime} \mathrm{W}$ to $44^{\circ} 20.717^{\prime} \mathrm{N}, 68^{\circ} 48.481^{\prime} \mathrm{W}$. Datum for all coordinates was WGS 84 . At each point, lichens were collected in bulk on several dates from June-October 2006 from soil, gravel, and rock within a five-meter radius of each sampling point (sampling area $78.5 \mathrm{~m}^{2}$ ). Collection areas are shown in Figure 1. Lichen species that had not been encountered around GP or WR were also collected from around the edges of mine roads 
throughout the site and Waste Rock Piles 2 and 3. Lichens were sought at the Tailings Pond but none were found.

Macrolichens and some microlichens were identified by T.B.H. using standard morphological and chemical methods. Verifications and additional identifications were provided by James W. Hinds (Univ. Maine, Orono), who determined macrolichens, and S.C., who determined the microlichens and some of the macrolichens. Nomenclature and naming authorities follow Index Fungorum Partnership (2010+) except where noted. Most of the macrolichens were deposited in the herbarium of College of the Atlantic (HCOA); microlichens and some macrolichens were deposited in the herbarium of the New Brunswick Museum (NBM).

To determine heavy metal concentrations in the top soils, soil/ sediment samples were collected at nine locations at the Callahan Mine in June 2006. Three $100 \mathrm{~g}$ soil samples each were collected from GP (at beginning, mid, and end of transect), WR (one at the midpoint of each transect), and Tailings Pond (at beginning, mid, and end of one N-S transect across Pond). Soils were analyzed for bioavailable $\mathrm{Cd}, \mathrm{Cu}, \mathrm{Pb}$, and $\mathrm{Zn}$, metals known to be abundant at this site (Environmental Protection Agency 2003), by extraction with $0.005 \mathrm{M}$ diethylene triamine pentaacetic acid (DTPA) buffered with triethanolamine to $\mathrm{pH} 7.3$ (Lindsay and Norvell 1978) for two hours and subsequent detection by ICP-OES using matrix-matched calibration standards. The metal analyses were conducted by the Analytical Laboratory at the University of Maine at Orono.

\section{RESULTS}

We found 74 species of lichens, a lichenicolous fungus (Stigmidium sp.), and one ascomycete (Lichenothelia convexa) with uncertain biological status (Esslinger 2009; Appendix). Although it is not lichen-forming, we have included L. convexa in our list, as it is commonly found among saxicolous lichens. Of the lichens collected, 43 species were macrolichens (56.6\%) and 31 species were microlichens $(40.8 \%)$. Saxicolous lichens were the most abundant, with $65.8 \%$ (50 species) of the total flora; terricolous lichens consisted of $34.2 \%$ (26 species) of the total flora. Of the saxicolous lichens, $44 \%$ (22 species) were macrolichens while $52 \%$ (26 species) were microlichens. Of the terricolous lichens, 80.8\% (21 species) were macrolichens and $19.2 \%$ ( 5 species) were microlichens. 
Table 1. Bioavailable $\mathrm{Cu}, \mathrm{Zn}, \mathrm{Pb}$, and $\mathrm{Cd}$ content, given in ppm $(\mu \mathrm{g} / \mathrm{g}$ dry soil), in soil samples collected along Waste Rock Pile 1 (WR), Goose Pond (GP), and Tailings Pond (TP). Means ( \pm SE) based on three composite samples collected at beginning, mid, and end points of transects placed at the three sites. Significance ( $\mathrm{p}$ value $<0.05$ ) based on a one-way ANOVA.

\begin{tabular}{lcccc}
\hline \multicolumn{1}{c}{ Site } & $\mathrm{Cu}$ & $\mathrm{Zn}$ & $\mathrm{Pb}$ & $\mathrm{Cd}$ \\
\hline WR & $145.0( \pm 7.9)$ & $385.3( \pm 23.7)$ & $5.4( \pm 1.2)$ & $2.03( \pm 0.17)$ \\
GP & $102.2( \pm 2.1)$ & $688.1( \pm 10.4)$ & $3.9( \pm 0.07)$ & $7.7( \pm 0.04)$ \\
TP & $56.8( \pm 2.2)$ & $852.3( \pm 3.8)$ & $7.0( \pm 0.35)$ & $3.5( \pm 0.18)$ \\
Degrees of freedom & 2 & 2 & 2 & 2 \\
F value & 80.06 & 246.5 & 4.4 & 405.5 \\
p value & $<0.001$ & $<0.001$ & $>0.05$ & $<0.001$ \\
\hline
\end{tabular}

We found excessive concentrations of bioavailable $\mathrm{Cd}, \mathrm{Cu}, \mathrm{Pb}$, and $\mathrm{Zn}$ in the DTPA-extractable metal analysis of soils collected at GP, WR, and TP (Table 1). Of the 76 lichens and fungi we documented, we recognized 19 species of lichens from the Callahan mine (25\% of total flora collected) that had been documented in previous studies as tolerant of or accumulating high concentrations of $\mathrm{Cd}, \mathrm{Cu}, \mathrm{Pb}$, and $\mathrm{Zn}$ worldwide (Table 2).

\section{DISCUSSION}

Most of the lichens encountered at the Callahan Mine were ecological generalists that are not narrowly restricted to a particular substratum or habitat type. A high proportion of the species have life histories characterized by relatively precocious and abundant production of ascospores or vegetative propagules. Such traits confer an advantage in frequently disturbed habitats. Examples of such species at the Callahan Mine include: Acarospora fuscata, Amandinea punctata, Caloplaca holocarpa, Candelariella vitellina, Cladonia cariosa, C. rei, Dibaeis baeomyces, Lecanora dispersa, $L$. polytropa, Leimonis erratica, Melanelixia subaurifera, Peltigera rufescens, Physcia dubia, Placynthiella icmalea, Porpidia crustulata, Rhizocarpon reductum, Scoliciosporum umbrinum, Stereocaulon tomentosum, Trapeliopsis granulosa, and Verrucaria muralis (Brodo et al. 2001; Hinds and Hinds 2007; Smith et al. 2009; Appendix).

Species characteristic of nutrient-enriched substrata were also well represented, although it is unclear whether the nutrient enrichment was via organic matter, including bird and other animal 
Table 2. Nineteen lichen species from the Callahan Mine previously documented to tolerate or accumulate elevated levels of $\mathrm{Cd}, \mathrm{Cu}, \mathrm{Pb}$, and $\mathrm{Zn}$.

\begin{tabular}{|c|c|c|}
\hline Species & Metal & Reference \\
\hline \multirow[t]{2}{*}{ Acarospora smaragdula } & $\mathrm{Cu}$ & $\begin{array}{l}\text { Garty 1993; Pawlik-Skowrońska } \\
\text { et al. 2006; Purvis et al. 1985; } \\
\text { Purvis 1996; Purvis and Halls } \\
\text { 1996; Wedin et al. } 2009\end{array}$ \\
\hline & $\mathrm{Pb}$ & Purvis et al. 2000 \\
\hline Cladonia cariosa & $\mathrm{Pb}, \mathrm{Zn}$ & $\begin{array}{l}\text { Purvis 1996; Purvis and Halls } \\
1996\end{array}$ \\
\hline C. chlorophaea & $\mathrm{Pb}$ & Garty 1993 \\
\hline C. cristatella & $\mathrm{Cd}, \mathrm{Pb}$ & Garty 1993 \\
\hline C. furcata & $\mathrm{Pb}, \mathrm{Zn}$ & $\begin{array}{l}\text { Garty 1993; Pawlik-Skowrońska } \\
\text { et al. } 2008\end{array}$ \\
\hline C. pyxidata & $\mathrm{Pb}$ & Garty 1993 \\
\hline C. rangiferina & $\mathrm{Cd}, \mathrm{Pb}$ & Garty 1993 \\
\hline C. rei & $\mathrm{Pb}, \mathrm{Zn}$ & Purvis and Halls 1996 \\
\hline Dibaeis baeomyces & $\mathrm{Pb}, \mathrm{Zn}$ & Purvis and Halls 1996 \\
\hline \multirow[t]{4}{*}{ Hypogymnia physodes } & $\mathrm{Cd}, \mathrm{Pb}$ & Conti et al. 2001; Garty 1993 \\
\hline & $\mathrm{Cu}$ & Garty 1993 \\
\hline & $\mathrm{Zn}$ & Garty 1993 \\
\hline & $\mathrm{Pb}, \mathrm{Zn}$ & Pawlik-Skowrońska et al. 2008 \\
\hline Lecanora dispersa & $\mathrm{Pb}$ & Garty 1993 \\
\hline L. polytropa & $\mathrm{Cu}$ & $\begin{array}{l}\text { Alstrup \& Hansen 1977; Garty } \\
\text { 1993; Pawlik-Skowrońska et } \\
\text { al. 2006; Purvis 1996; Purvis } \\
\text { and Halls 1996; Purvis et al. } \\
\text { 2008 }\end{array}$ \\
\hline Parmelia sulcata & $\mathrm{Pb}, \mathrm{Zn}$ & Garty 1993 \\
\hline \multirow[t]{2}{*}{ Peltigera rufescens } & $\mathrm{Cu}$ & Baèkor et al. 2009 \\
\hline & $\mathrm{Pb}, \mathrm{Zn}$ & Garty 1993 \\
\hline Physcia adscendens & $\mathrm{Pb}, \mathrm{Zn}$ & Pawlik-Skowrońska et al. 2008 \\
\hline Rhizocarpon cinereovirens & $\mathrm{Pb}, \mathrm{Zn}$ & Purvis and Halls 1996 \\
\hline Stereocaulon dactylophyllum & $\mathrm{Pb}, \mathrm{Zn}$ & Purvis 1996 \\
\hline S. pileatum & $\mathrm{Pb}, \mathrm{Zn}$ & $\begin{array}{l}\text { Purvis 1996; Purvis and Halls } \\
1996\end{array}$ \\
\hline \multirow{2}{*}{ Xanthoria parietina } & $\mathrm{Cd}$ & Rossbach and Lambrecht 2006 \\
\hline & $\mathrm{Pb}$ & $\begin{array}{l}\text { Garty 1993; Rossbach and } \\
\text { Lambrecht 2006; Sarret et al. } \\
1998\end{array}$ \\
\hline
\end{tabular}

droppings, or via salt spray or deposition of nitrogenous pollutants. The occurrence of a number of calciphilous species may be linked to the presence of old mortar or concrete at the site (Brodo et al. 2001; Smith et al. 2009). Among these are Candelariella aurella, Cladonia 
cariosa, C. pocillum, Lecanora dispersa, Leptogium imbricatum, and Verrucaria muralis (Appendix).

Species found at the site that are metal tolerant (Table 2; Appendix) often occur in a range of habitats in the Northeast. However, 19 lichen species encountered at the Callahan Mine (25\% of total flora documented) appear to frequent mine tailings and other metal-enriched sites worldwide (Table 2). Iron-tolerant species were also frequent at the site and included Acarospora sinopica, A. smaragdula, Candelariella vitellina, Lecanora polytropa, Porpidia macrocarpa, Rhizocarpon cinereovirens, $R$. infernulum, $R$. lecanorinum, $R$. reductum, Scoliciosporum umbrinum, and Stereocaulon dactylophyllum (Brodo et al. 2001; Smith et al. 2009). Of these, only $A$. sinopica is largely restricted to iron-rich substrata (Appendix). Acarospora smaragdula and several other species (Table 2) tolerate elevated levels of a range of heavy metals, including $\mathrm{Cd}, \mathrm{Cu}, \mathrm{Pb}$, and $\mathrm{Zn}$ (Purvis and Halls 1996). It is likely that the warm, dry weather encountered during the collection period precluded the collection of spring-time ephemeral species typical of this type of environment, such as those of the genus Vezdaea (Coppins 1987; Gilbert 2004). Species in this genus and other terricolous microlichens common to metal-contaminated soils are generally very inconspicuous and are fertile during specific times of year; as such, they may have been easily overlooked in our study.

No globally rare or declining macrolichen species were found at the Callahan Mine. However, two regionally rare or declining macrolichens (Hinds and Hinds 2007) were present: Stereocaulon tomentosum (R2; approximately 20 known sites, including 19 in Maine and one in New Hampshire) and Leptogium imbricatum (R1; currently known in New England from a single site in Washington County, Maine). Stereocaulon tomentosum was found in at least five New England states prior to 1930. However, it seems to have become restricted to Maine and New Hampshire since the 1980s (Hinds and Hinds 2007).

Remedial investigations conducted by the EPA from 2004-2008 confirmed that the Callahan Mine and the surrounding area were contaminated by elevated levels of heavy metals and other organic contaminants; the total concentrations of $\mathrm{As}, \mathrm{Cu}, \mathrm{Pb}$, and $\mathrm{Zn}$, as well as PCBs were found to be many-fold greater than levels acceptable for human contact or ecosystem health (Environmental Protection Agency 2009). Our soil analyses (Table 1) support the findings of the EPA, showing elevated concentrations of bioavail- 
able $\mathrm{Cd}, \mathrm{Cu}, \mathrm{Pb}$, and $\mathrm{Zn}$ at our sampling locations. Further, concentrations of all metals exceeded the upper limit reported for 'normal' surface soils globally (Kabata-Pendias 2001; Nash 1989), suggesting increased potential for toxicity and bioaccumulation.

Previous studies at the Callahan Mine have reported ore rocks and mine tailings containing total $\mathrm{Zn}$ concentrations of $17 \%$ $(170,000 \mathrm{ppm})$ and $0.71 \%(7100 \mathrm{ppm})$, respectively (Environmental Protection Agency 2003). These concentrations are highly toxic to organisms and exceed the upper total concentrations $(<500 \mathrm{ppm})$ reported for this metal from surface soils globally (Kabata-Pendias 2001; Nash 1989). All three of our sampling locations at the Callahan Mine (Table 1) recorded high mean bioavailable Zn (383$852 \mathrm{ppm}$ ) at concentrations potentially toxic to the resident biota, including lichens. A recent EPA study reported that salt grass [Distichlis spicata (L.) Greene] at the Callahan Mine accumulated 54 times more $\mathrm{Zn}$ than the same taxon collected from 'unpolluted' reference locations (Environmental Protection Agency 2009).

A similar trend was documented for $\mathrm{Cu}$ at the Callahan Mine, a metal far exceeding the normal background total concentrations $(<$ 120 ppm) in soil (Fernandes and Henriques 1991; Kabata-Pendias 2001; Nash 1989). Ore and tailings of the Callahan Mine contained approximately $7 \%(70,000 \mathrm{ppm})$ and $0.15 \%(1500 \mathrm{ppm})$ total $\mathrm{Cu}$, respectively (Environmental Protection Agency 2003). Our soil analyses report mean bioavailable $\mathrm{Cu}$ concentrations (57-145 ppm; Table 1); these levels are known to cause acute toxicity in organisms, including in lichens (Fernandes and Henriques 1991). The EPA report documents salt grass at the Callahan Mine accumulating 79 times more $\mathrm{Cu}$ than the same taxon collected from 'unpolluted' reference locations (Environmental Protection Agency 2009).

Normal background levels of total $\mathrm{Pb}$ in soils from Maine range from 10-50 ppm (Bruce Hoskins, Analytical Laboratory, Univ. Maine, Orono, pers. comm.), whereas worldwide the upper limit has been reported as 70-100 ppm (Kabata-Pendias 2001; Nash 1989). The amounts of $\mathrm{Pb}$ extracted from chelators such as DTPA, used in our analysis (4-7 ppm; Table 1), are much less than the total content but give a better index of bioavailability (Cui et al. 2004). Given that the ore and mine tailings contained an average of 5\% $(50,000 \mathrm{ppm})$ and $0.06 \%(600 \mathrm{ppm})$ total $\mathrm{Pb}$, respectively (Environmental Protection Agency 2003), the bioavailable values we report in Table 1 are much lower. However, the EPA studies 
document that all organisms tested in and around the Callahan Mine (benthic, aquatic, and salt grass) accumulated significantly higher concentrations of $\mathrm{Pb}$ than the same taxa collected from 'unpolluted' reference locations (Environmental Protection Agency 2009). For example, salt grass at the Callahan Mine accumulated 14 times more lead than the same taxon collected from the reference locations.

Our ongoing studies of lichens of metal-enriched substrates in Maine point to an interesting trend. The Callahan Mine (this study) and the Ni-enriched serpentine outcrop at Pine Hill shared in common 22 species (29\% of the total flora documented), including Buellia ocellata, a species that we reported for the first time in New England (Harris et al. 2007). Ecologically, the lichen flora at the Callahan Mine showed a similar species composition to that of Pine Hill, with a greater percentage of saxicolous species compared to terricolous species, and a relatively higher percentage of microlichens among the saxicolous species compared to a significantly greater percentage of macrolichens among the terricolous species. Favero-Longo et al. (2004), in a review of lichens of serpentine substrates worldwide, suggested that many species occupying $\mathrm{Cr}-$ and Ni-enriched serpentine substrates can also be found on other calcareous and siliceous substrates. Six of the 76 species we documented (ca. 8\%) were also collected from a calcium-rich spring seep isolated on the granitic terrain of Mt. Katahdin, Maine's tallest mountain (Miller et al. 2005), whereas 35 species (ca. $46 \%$ ) were shared in common with the subalpine and alpine lichen floras of Katahdin (Dibble et al. 2009; Hinds et al. 2009). Several species known to occur on nutrient-enriched bird nesting rocks were also found at the Callahan Mine. They include Physcia dubia and $P$. phaea (Hinds and Hinds 2007), Acarospora fuscata and Amandinea punctata (Smith et al. 2009), and Xanthoria parietina (Rajakaruna et al. 2009b). These observations suggest that chemically and physically harsh substrates, or alpine climates, that prevent the formation of dense vascular vegetation in exposed sites can provide a competition-free refuge for various lichen species in the region. We hope that this and other studies we have conducted in the recent past (Rajakaruna et al. 2009a) will generate additional field exploratory work documenting the biodiversity of unusual habitats - especially rock outcrops - across New England.

ACKNOWLEDGMENTS. The authors thank Laura Briscoe and Anthony Naples for assistance with lichen collection and initial 
identification of specimens, James W. Hinds for verifications and identification of the macrolichens, and José Perez Orozco for the preparation of Figure 1. For permission to access the Callahan Mine, we thank: Sally N. Mills (Hale \& Hamlin, LLC), the Maine Department of Environmental Protection, the Environmental Protection Agency, and the Maine Department of Transportation. Two anonymous reviewers provided useful comments. The study was funded by grants from the Maine Space Grant Consortium to T.B.H. and N.R. and from the Maine Sea Grant (DV-05-009) to N.R.

\section{LITERATURE CITED}

Alstrup, V. and E. S. Hansen. 1977. Three species of lichens tolerant of high concentrations of copper. Oikos 29: 290-293.

Aznar, J.-C., M. Richer-LAflèche, And D. Cluis. 2008. Metal contamination in the lichen Alectoria sarmentosa near the copper smelter of Murdochville, Québec. Environm. Pollut. 156: 76-81.

BaČKor, M., B. Klejdus, I. Vantova, And J. KováčiK. 2009. Physiological adaptations in the lichens Peltigera rufescens and Cladina arbuscula var. mitis, and the moss Racomitrium lanuginosum to copper-rich substrate. Chemosphere 76: 1340-1343.

- AND S. LopPI. 2009. Interactions of lichens with heavy metals. Biol. Pl. 53: 214-222.

Brodo, I. M., S. D. Sharnoff, and S. Sharnoff. 2001. Lichens of North America. Yale Univ. Press, New Haven, CT.

Chaney, R. L., J. S. Angle, C. L. Broadhurst, C. A. Peters, R. V. Tappero, AND D. L. SPARKs. 2007. Improved understanding of hyperaccumulation yields commercial phytoextraction and phytomining technologies. J. Environm. Qual. 36: 1429-1443.

Chisholm, J. E., C. G. Jones, and O. W. Purvis. 1987. Hydrated copper oxalate, moolooite in lichens. Mineral. Mag. 51: 715-718.

Church, J. M., B. J. Coppins, O. L. Gilbert, P. W. James, and N. F. Stewart. 1996. Red Data Books of Britain and Ireland: Lichens, Vol. 1. Joint Nature Conservation Committee, Peterborough, U.K.

Conti, M. E. and G. Cecchetti. 2001. Biological monitoring: Lichens as bioindicators of air pollution assessment: A review. Environm. Pollut. 114: 471-492.

Coppins, B. J. 1987. The genus Vezdaea in the British Isles. Lichenologist 10: $167-176$.

Cui, Y., Q. Wang, Y. Dong, H. Li, and P. Christie. 2004. Enhanced uptake of soil $\mathrm{Pb}$ and $\mathrm{Zn}$ by Indian mustard and winter wheat following combined soil application of elemental sulphur and EDTA. Pl. \& Soil 261: 181-188.

Dibble, A. C., N. G. Miller, J. W. Hinds, and A. M. Fryday. 2009. Lichens and bryophytes of the alpine and subalpine zones of Katahdin, Maine. 1. Overview, ecology, climate, and conservation aspects. Bryologist 112: $651-672$. 
Easton, R. M. 1994. Lichens and rocks: A review. Geosci. Canad. 21: 59-76.

Environmental Protection Agency. 2002. National priorities list site narrative for Callahan Mine. U.S. EPA, OSRTI, Washington, DC. Website (http:// www.epa.gov/superfund/sites/npl/nar1646.htm). Most recently accessed Dec 2009.

- 2003. Conceptual model and RI/FS SOW, Callahan Mining superfund site, Brookville, Maine. EPA Contract 68-W6-0042. Metcalf and Eddy, Inc., Wakefield, MA. Website (http://www.epa.gov/ne/superfund/sites/ callahan/44290.pdf). Most recently accessed 14 Dec 2009.

2009. Callahan Mining Corporation public information meeting for proposed cleanup plan. SDMS\# 452697. U.S. EPA, Region 1, Boston, MA. Website (http://www.epa.gov/region1/superfund/sites/callahan/ 452697.pdf). Most recently accessed 14 Dec 2009.

Esslinger, T. L. 2009. A cumulative checklist for the lichen-forming, lichenicolous, and allied fungi of the continental United States and Canada. North Dakota State Univ., Fargo, ND. Website (http://www. ndsu.nodak.edu/instruct/esslinge/chcklst/chcklst7.htm). Most recently accessed 11 Dec 2009.

Favero-Longo, S. E., D. Isocronso, and R. Piervittori. 2004. Lichens and ultramafic rocks: A review. Lichenologist 36: 391-404.

Fernandes, J. C. And F. S. Henriques. 1991. Biochemical, physiological, and structural effects of excess copper in plants. Bot. Rev. 57: 246-273.

GARTY, J. 1993. Lichens as biomonitors for heavy metal pollution, pp. 193-263. In: B. Markert, ed., Plants as Biomonitors: Indicators for Heavy Metals in the Terrestrial Environment. VCH, Cambridge, U.K.

- 2001. Biomonitoring atmospheric heavy metals with lichens: Theory and application. Crit. Rev. Pl. Sci. 20: 309-371.

Gilbert, O. L. 2004. The phenology of Sarcosagium campestre observed over three years. Lichenologist 36: 159-161.

Harris, T. B., F. C. Olday, and N. Rajakaruna. 2007. Lichens of Pine Hill, a peridotite outcrop in eastern North America. Rhodora 109: 430-447.

Harrison, S. P. and N. Rajakaruna, eds. 2011. Serpentine: Evolution and Ecology in a Model System. Univ. California Press, Berkeley, CA.

Hinds, J. W., A. M. Fryday, And A. C. Dibble. 2009. Lichens and bryophytes of the alpine and subalpine zones on Katahdin, Maine. 2. Lichens. Bryologist 112: 673-703.

And P. L. Hinds. 2007. The Macrolichens of New England. The New York Botanical Garden Press, New York, NY.

Index Fungorum Partnership. 2010+. Index Fugorum. A community resource. CABI, CBS, and Landcare Research, custodians. CABI, Wallingford, Oxfordshire, U.K.; CBS KNAW Fungal Biodiversity Centre, Utrecht, The Netherlands; and Manaaki Whenua - Landcare Research, Lincoln, New Zealand. Website (http://www.indexfungorum.org). Most recently accessed Jan 2010.

Kabata-Pendias, A. 2001. Trace Elements in Soils and Plants, 3rd ed. CRC Press, Boca Raton, FL.

Kirchner, G. and O. Daillant. 2002. The potential of lichens as long-term biomonitors of natural and artificial radionuclides. Environm. Pollut. 120: $145-150$. 
Lepage, C. A., M. E. Foley, and W. B. Thompson. 1991. Mining in Maine: Past, present, and future. Open-File 91-7, Maine Geological Survey, Augusta, ME. Website (http://www.maine.gov/doc/nrimc/mgs/explore/ mining/minemaine.htm). Most recently accessed 11 Dec 2009.

Lindsay, W. L. AND W. A. Norvell. 1978. Development of a DTPA soil test for zinc, iron, manganese, and copper. J. Soil Sci. 42: 421-428.

Marques, A. P. G. C., A. O. S. S. Rangel, and P. M. L. Castro. 2009. Remediation of heavy metal contaminated soils: Phytoremediation as a potentially promising cleanup technology. Crit. Rev. Environm. Sci. Technol. 39: 622-654.

McLean, J., O. W. Purvis, B. J. Williamson, and E. H. Bailey. 1998. Role for lichen melanins in uranium remediation. Nature 391: 649-650.

Miller, N. G., A. M. Fryday, And J. W. Hinds. 2005. Bryophytes and lichens of a calcium-rich spring seep isolated on the granitic terrain of Mt. Katahdin, Maine, U.S.A. Rhodora 107: 339-358.

NASH, T. H. 1989. Metal tolerance in lichens, pp. 119-131. In: A. J. Shaw, ed., Heavy Metal Tolerance in Plants: Evolutionary Aspects. CRC Press, Boca Raton, FL.

Pawlik-Skowrońska, B., O. W. Purvis, J. Pirszel, and T. Skowroński. 2006. Cellular mechanisms of $\mathrm{Cu}$-tolerance in the epilithic lichen Lecanora polytropa growing at a copper mine. Lichenologist 38: 267-275.

—, H. WóJCIAK, AND T. SKOWRoŃSKi. 2008. Heavy metal accumulation, resistance, and physiological status of some epigeic and epiphytic lichens inhabiting $\mathrm{Zn}$ and $\mathrm{Pb}$ polluted areas. Polish J. Ecol. 56: 195-207.

Pilon-Smits, E. A. H. and J. L. Freeman. 2006. Environmental cleanup using plants: Biotechnological advances and ecological considerations. Frontiers Ecol. Environm. 4: 203-210.

Purvis, O. W. 1984. The occurrence of copper oxalate in lichens growing on copper sulfide-bearing rocks in Scandinavia. Lichenologist 16: 197-204.

1993. The botanical interest of mine spoil heaps: The lichen story. J. Russell Soc. 5: 45-48.

1996. Interactions of lichens with metals. Sci. Progr. 79: 283-309.

, E. H. Bailey, J. Mclean, T. Kasama, and B. J. Williamson. 2004. Uranium biosorption by the lichen Trapelia involuta at a uranium mine. Geomicrobiol. J. 21: 159-167.

, J. P. Bennett, and J. Spratt. 2011. Copper localization, elemental content, and thallus colour in the copper hyperaccumulator lichen Lecanora sierrae from California. Lichenologist 43: 165-173.

, O. L. Gilbert, and P. W. James. 1985. The influence of copper on Acarospora smaragdula. Lichenologist 17: 111-114.

- AND C. Halls. 1996. A review of lichens in metal-enriched environments. Lichenologist 28: 571-601.

AND P. W. JAMES. 1985. Lichens of the Coniston copper mines. Lichenologist 17: 221-237.

AND B. PAwlik-SkowrońsKa. 2008. Lichens and metals, pp. 175-200. In: S. Avery, M. Stratford, and P. van West, eds., Stress in Yeasts and Filamentous Fungi. British Mycological Society Symposium Series, Elsevier \& Academic Press, Amsterdam, The Netherlands. 
G. Cressey, G. C. Jones, A. Kearsley, and J. Spratt. 2008. Mineral phases and element composition of copper hyperaccumulator lichen Lecanora polytropa. Mineral. Mag. 72: 607-616.

- B. J. Williamson, K. Bartok, and N. Zoltani. 2000. Bioaccumulation of lead by the lichen Acarospora smaragdula from smelter emissions. New Phytol. 147: 591-599.

Rajakaruna, N. AND R. S. Boyd. 2008. The edaphic factor, pp. 1201-1207. In: S. E. Jorgensen and B. Fath, eds., The Encyclopedia of Ecology, Vol. 2. Elsevier, Oxford, U.K.

, T. B. Harris, and E. B. Alexander. 2009a. Serpentine geoecology of eastern North America: A review. Rhodora 111: 21-108.

-, N. Pope, J. Perez-Orozco, and T. B. Harris. 2009b. Ornithocoprophilous plants of Mount Desert Rock, a remote bird-nesting island in the Gulf of Maine, U.S.A. Rhodora 111: 417-448.

Richardson, D. H. S. 1995. Metal uptake in lichens. Symbiosis 18: 119-127.

Rossbach, M. and S. LAmbrecht. 2006. Lichens as biomonitors: Global, regional, and local aspects. Croat. Chem. Acta 79: 119-124.

Sarret, G., A. Manceau, D. Cuny, C. van Haluwyn, S. Deruelle, J. L. Hazemann, Y. Soldo, L. Eybert-Berard, and J. J. Menthonnex. 1998. Mechanisms of lichen resistance to metallic pollution. Environm. Sci. Technol. 32: 3325-3330.

Smith, C. W., A. Aptroot, B. J. Coppins, A. Fletcher, O. L. Gilbert, P. W. James, And P. A. Wolseley, eds. 2009. The Lichens of Great Britain and Ireland. The British Lichen Society, London, U.K.

Wedin, M., M. Westberg, A. T. Crewe, A. Tehler, and O. W. Purvis. 2009. Species delimitation and evolution of metal bioaccumulation in the lichenized Acarospora smargdula (Ascomycota, Fungi) complex. Cladistics 25: $161-172$.

Whiting, S. N., ET AL. (2004). Research priorities for conservation of metallophyte biodiversity and their potential for restoration and site remediation. Restorat. Ecol. 12: 106-116. 


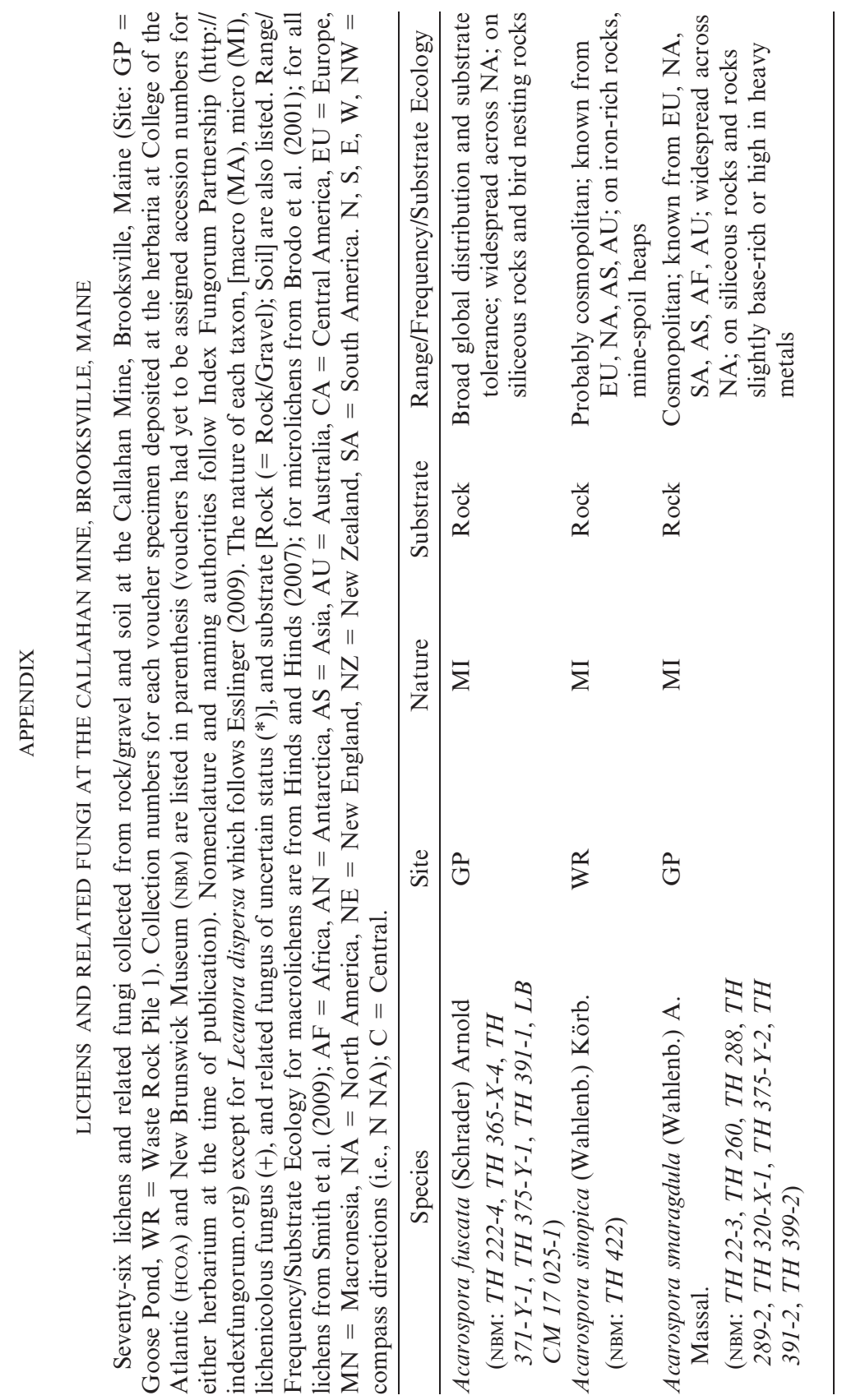




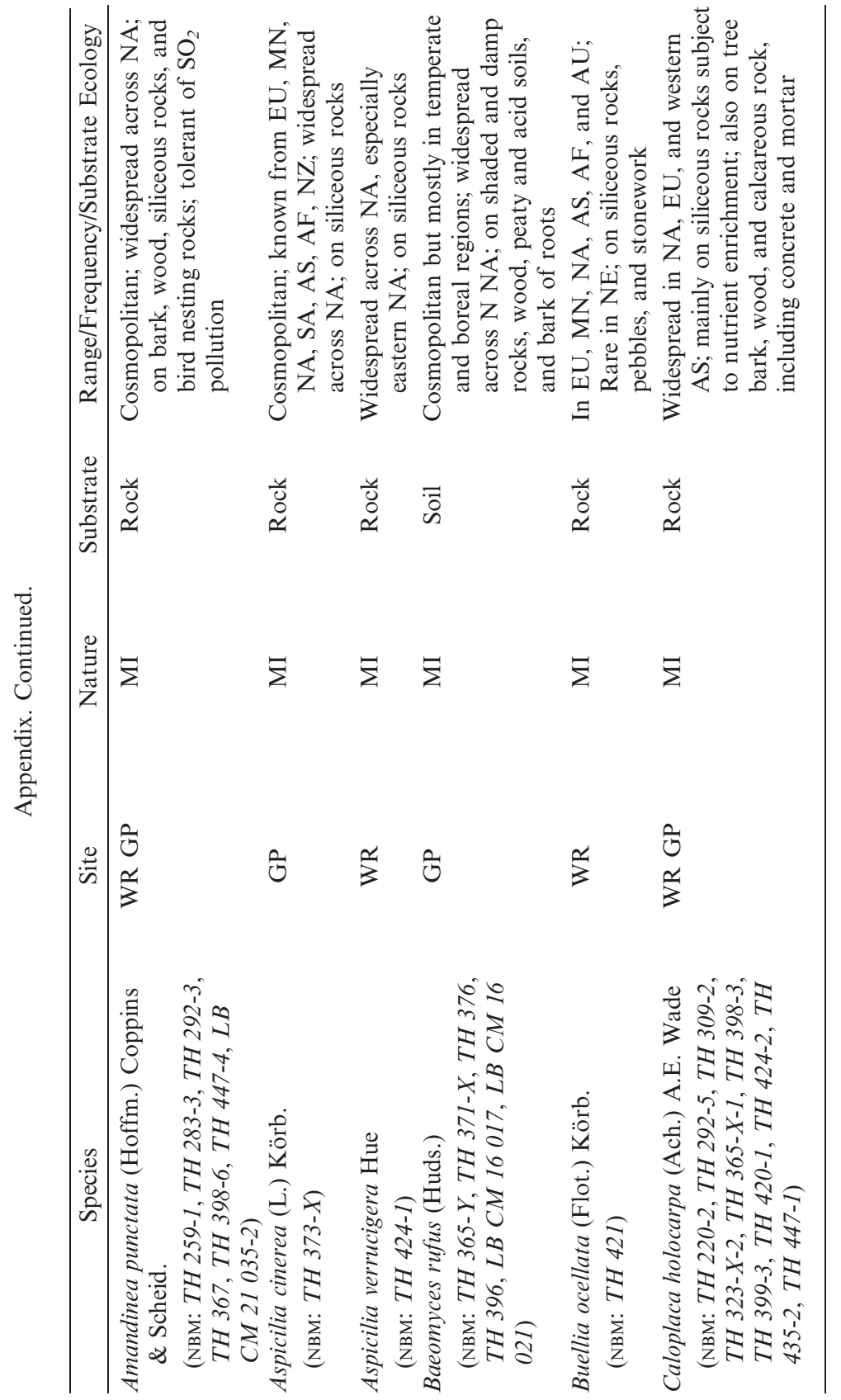




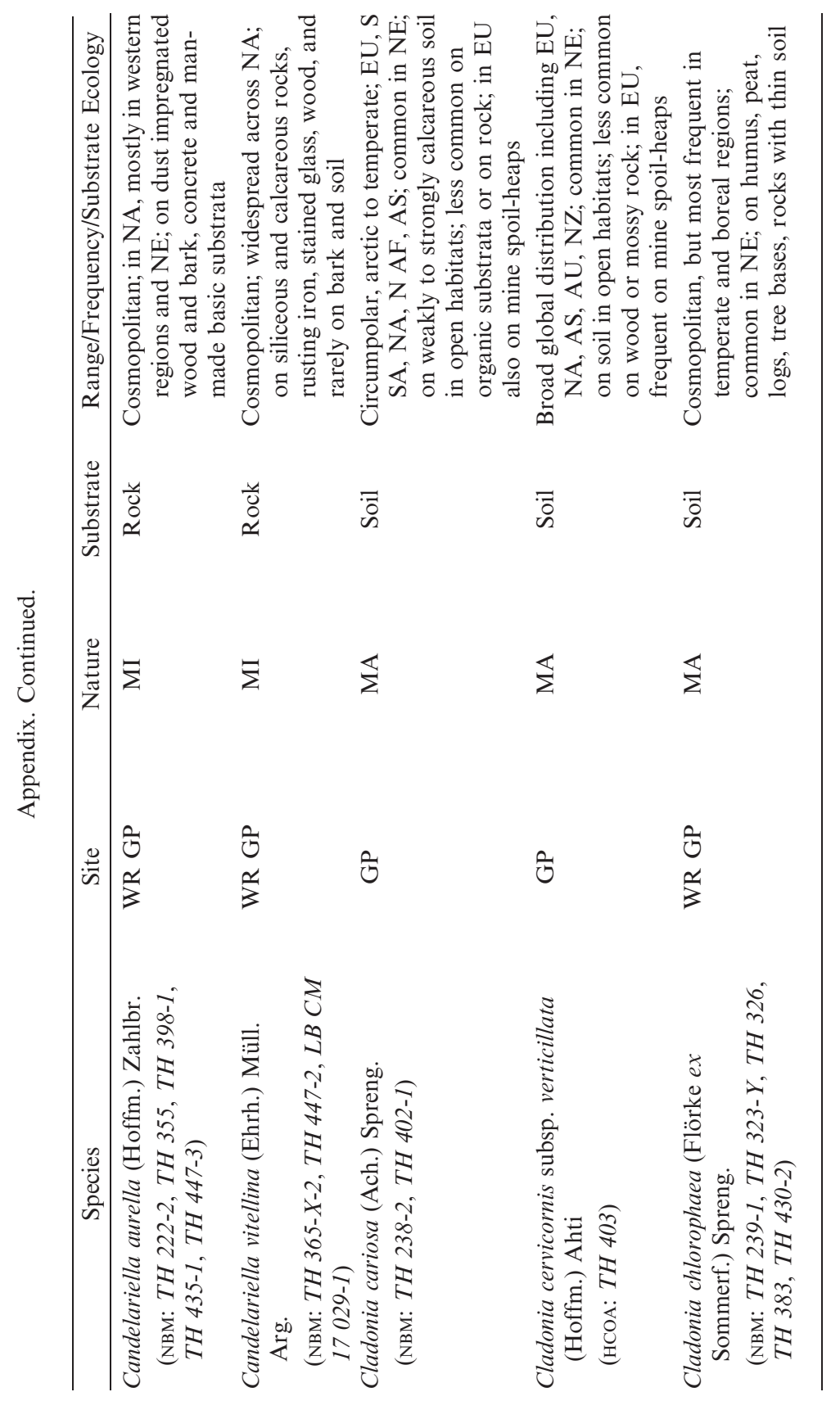




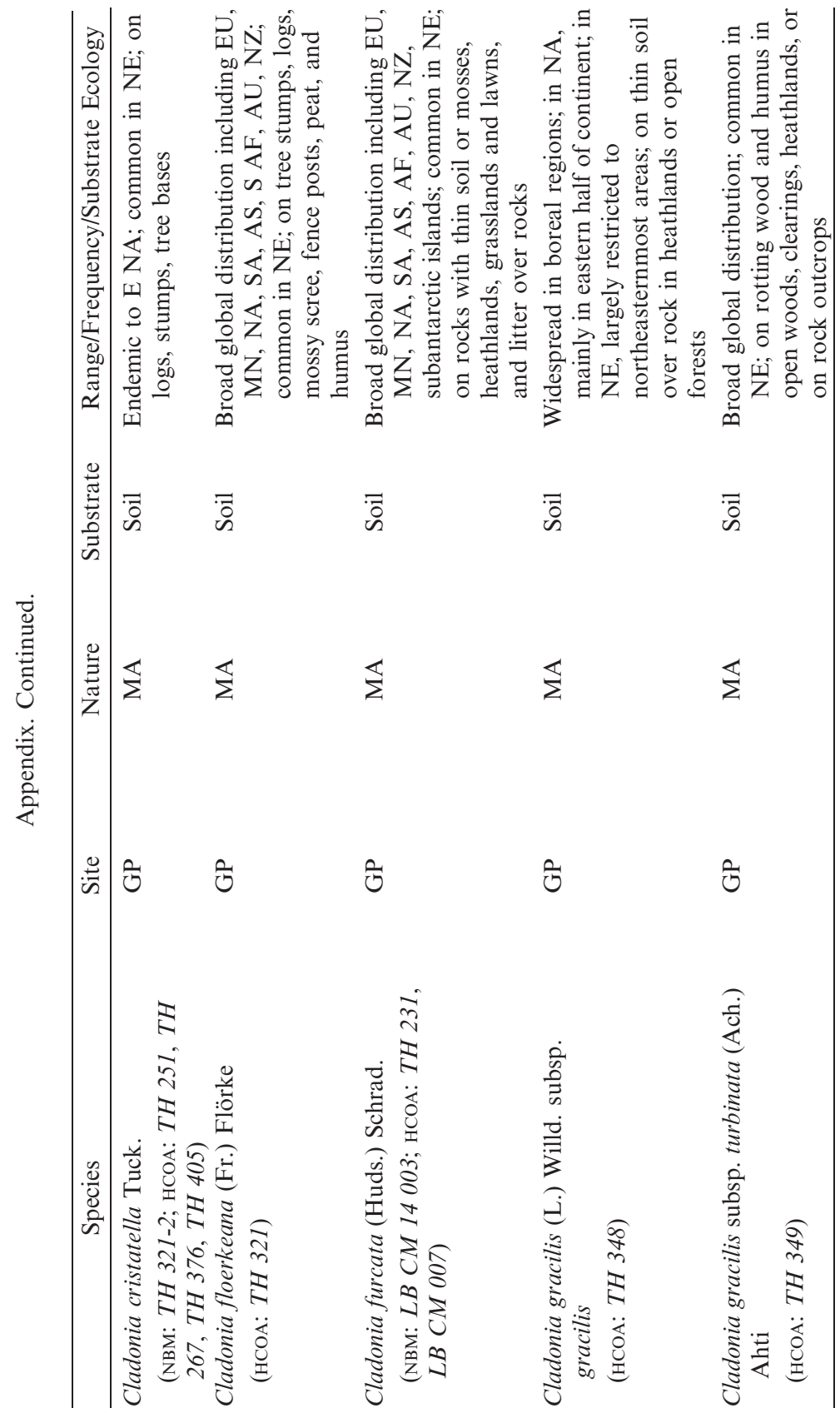




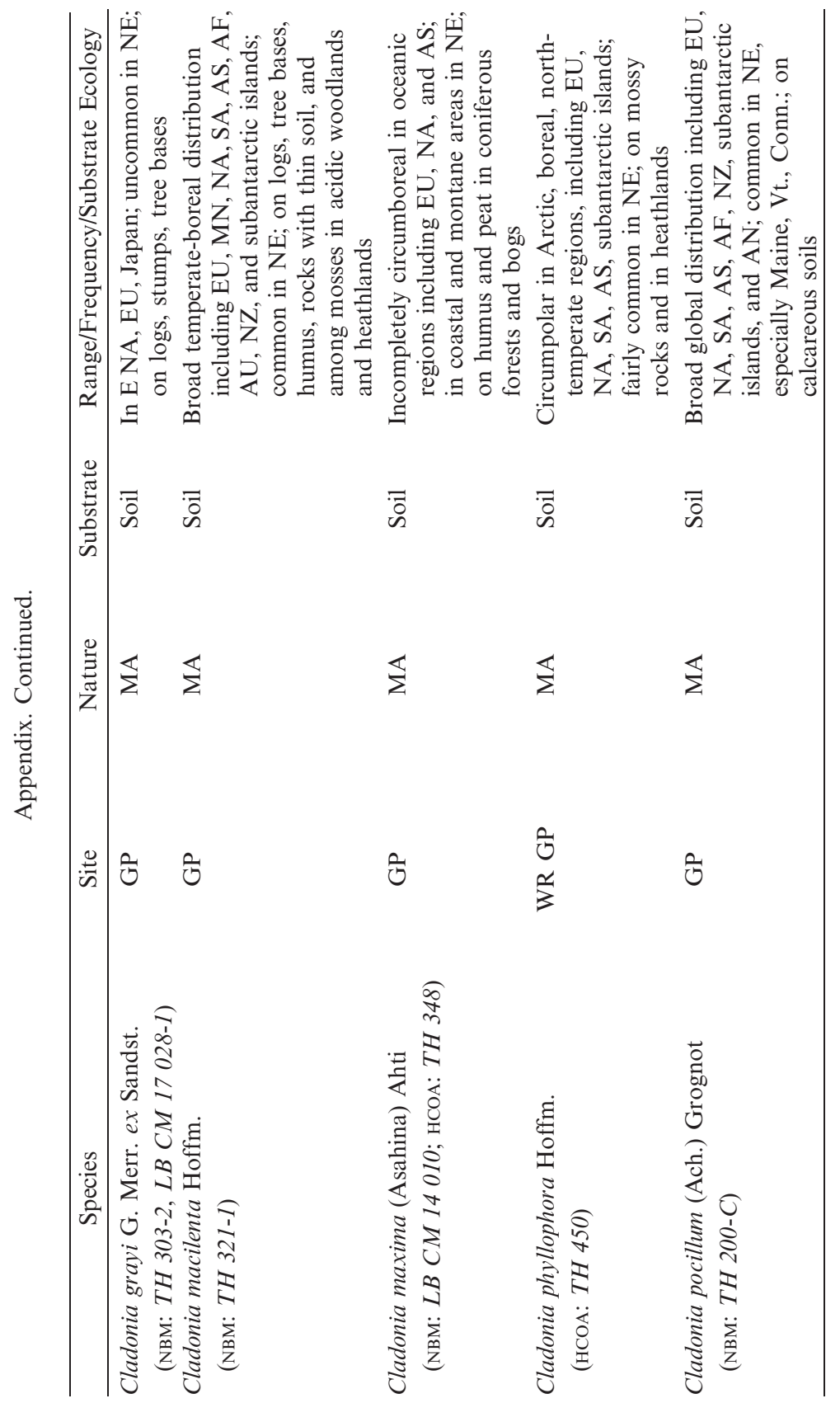




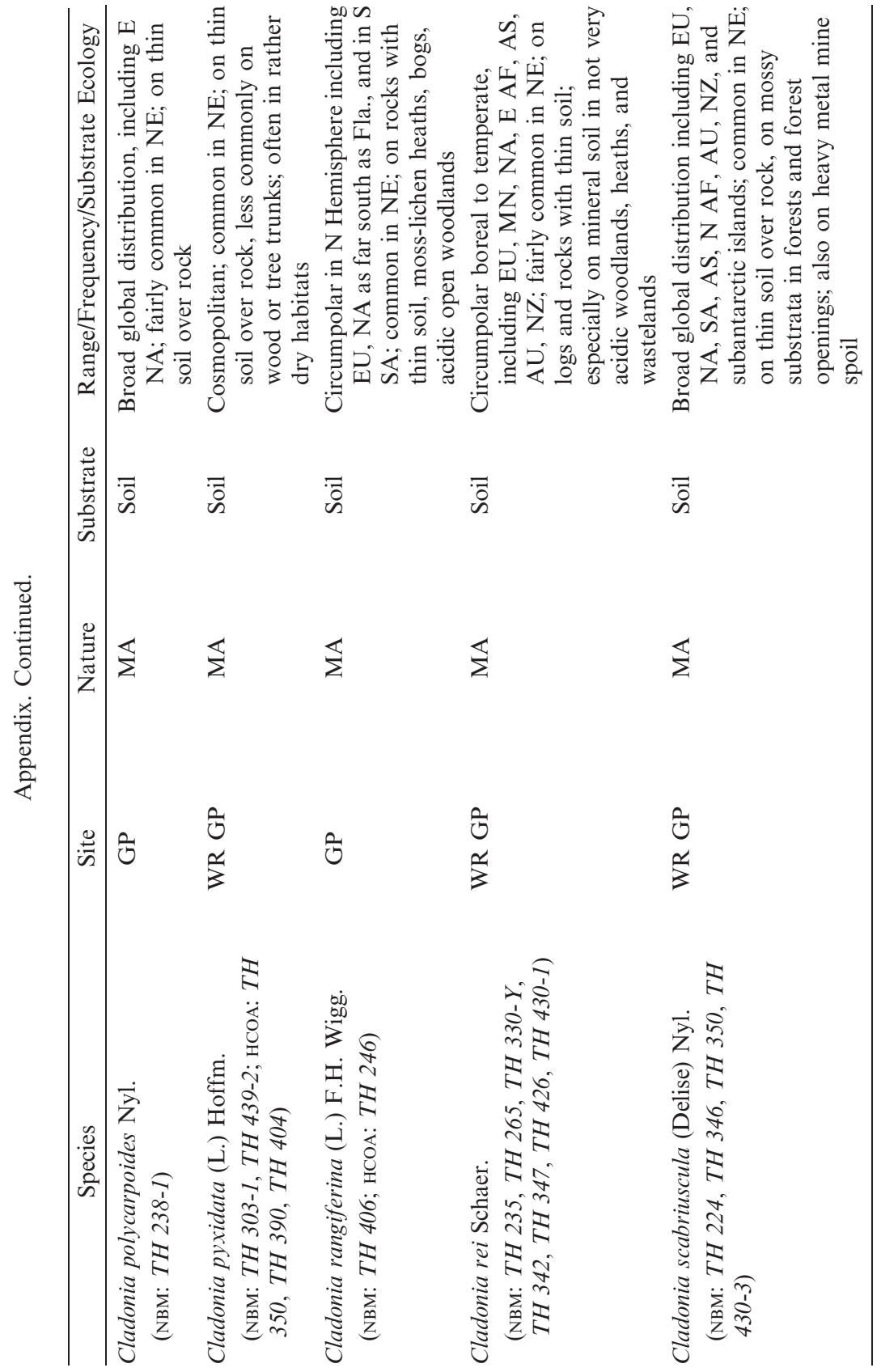




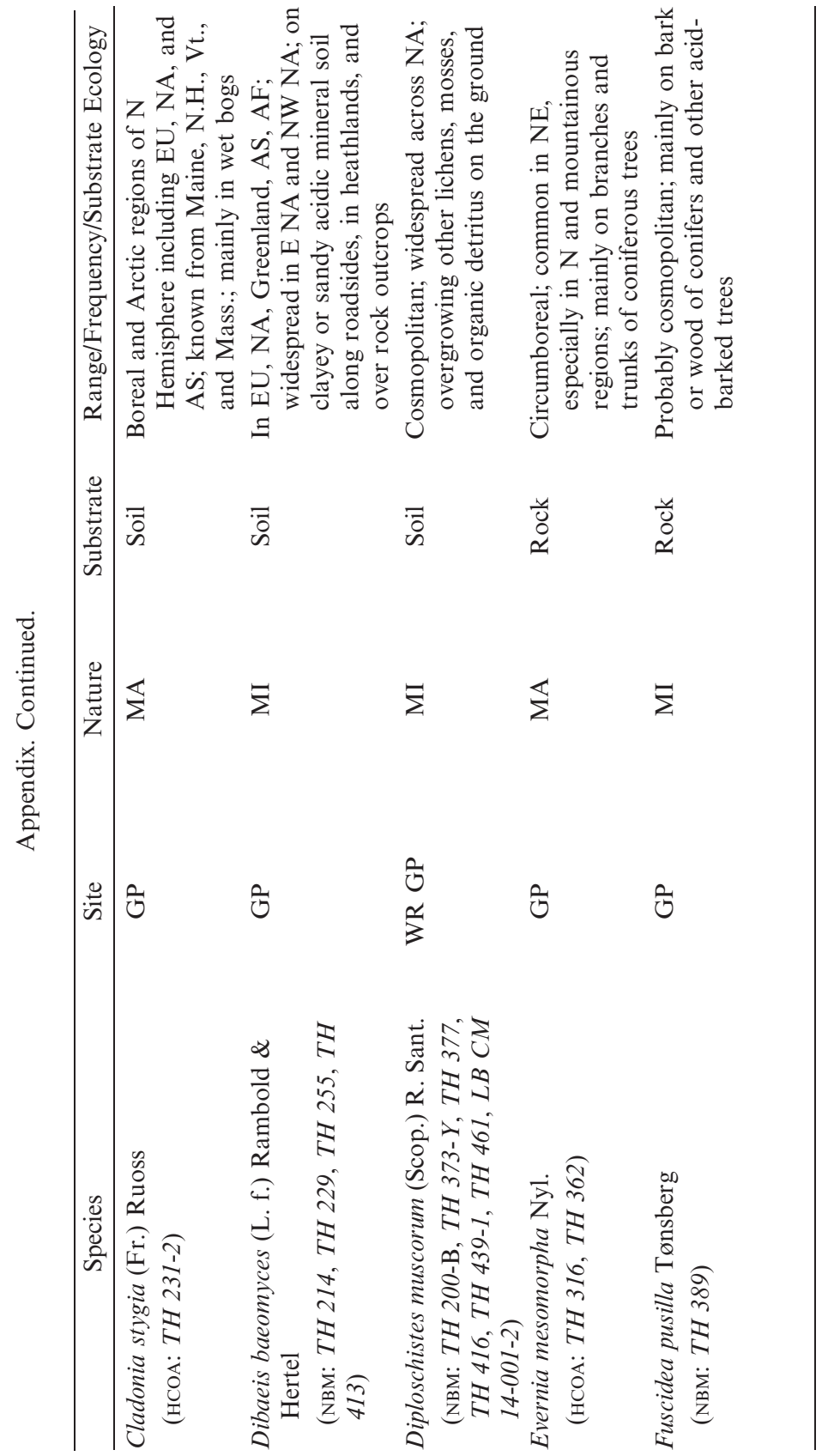




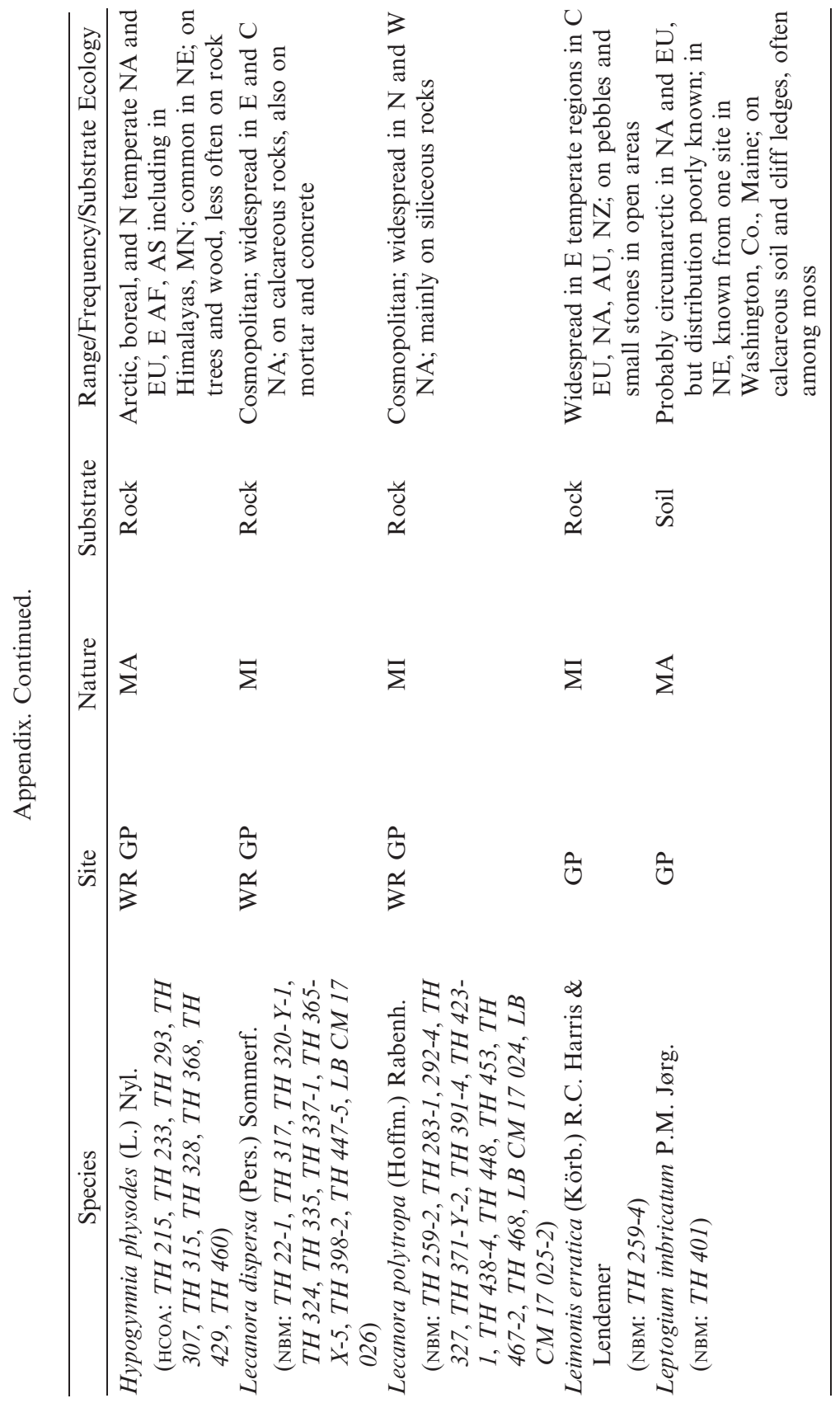




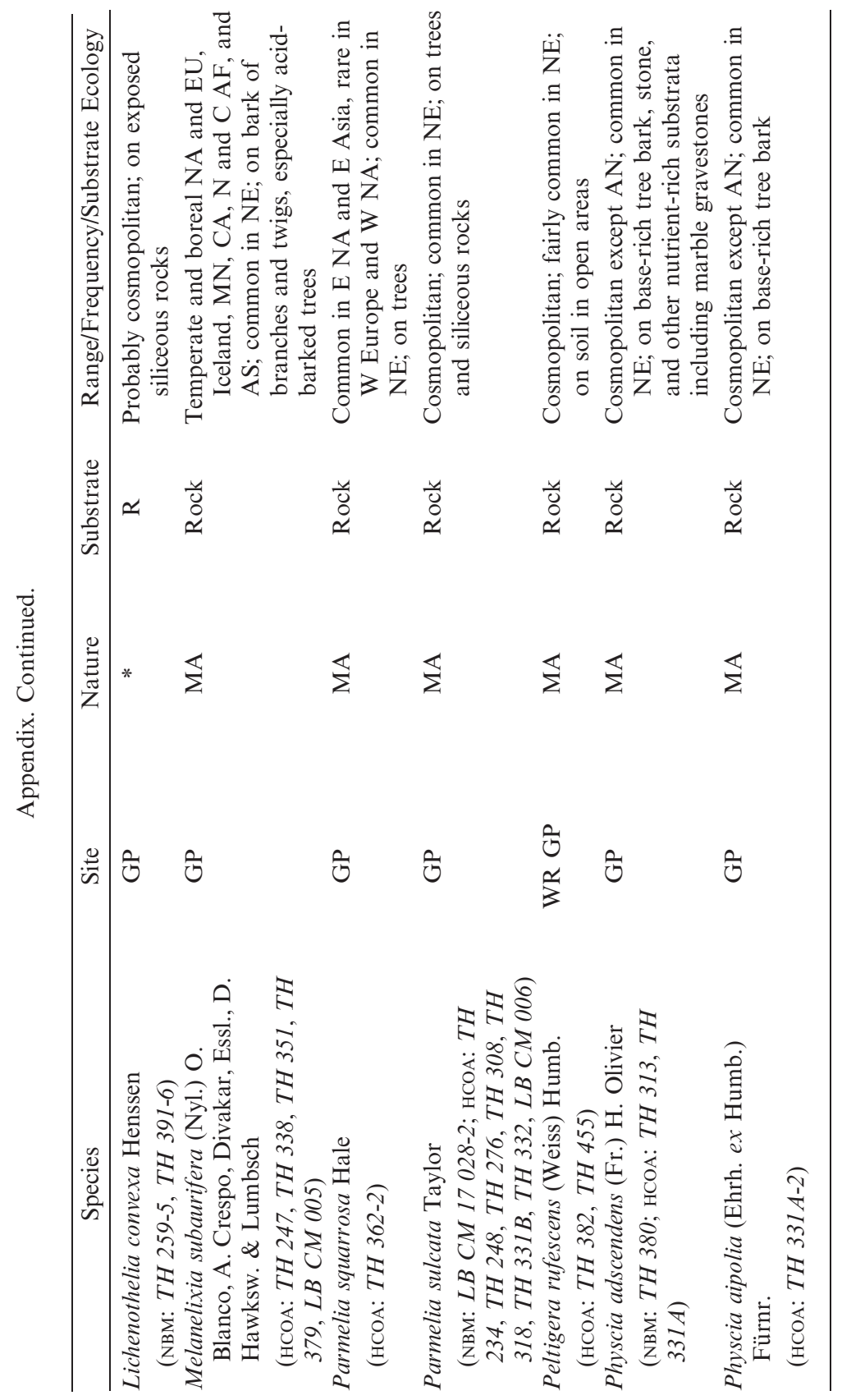




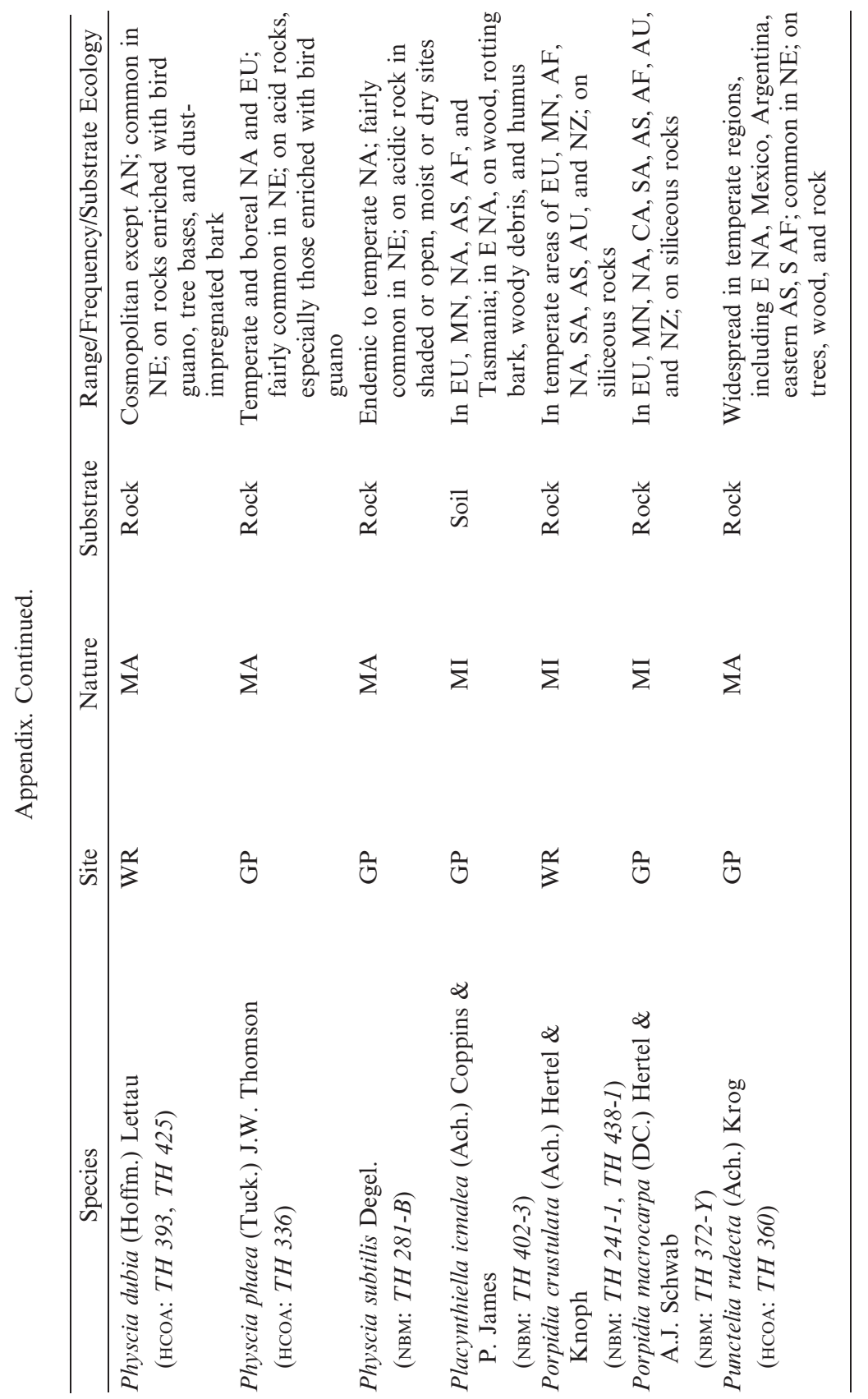




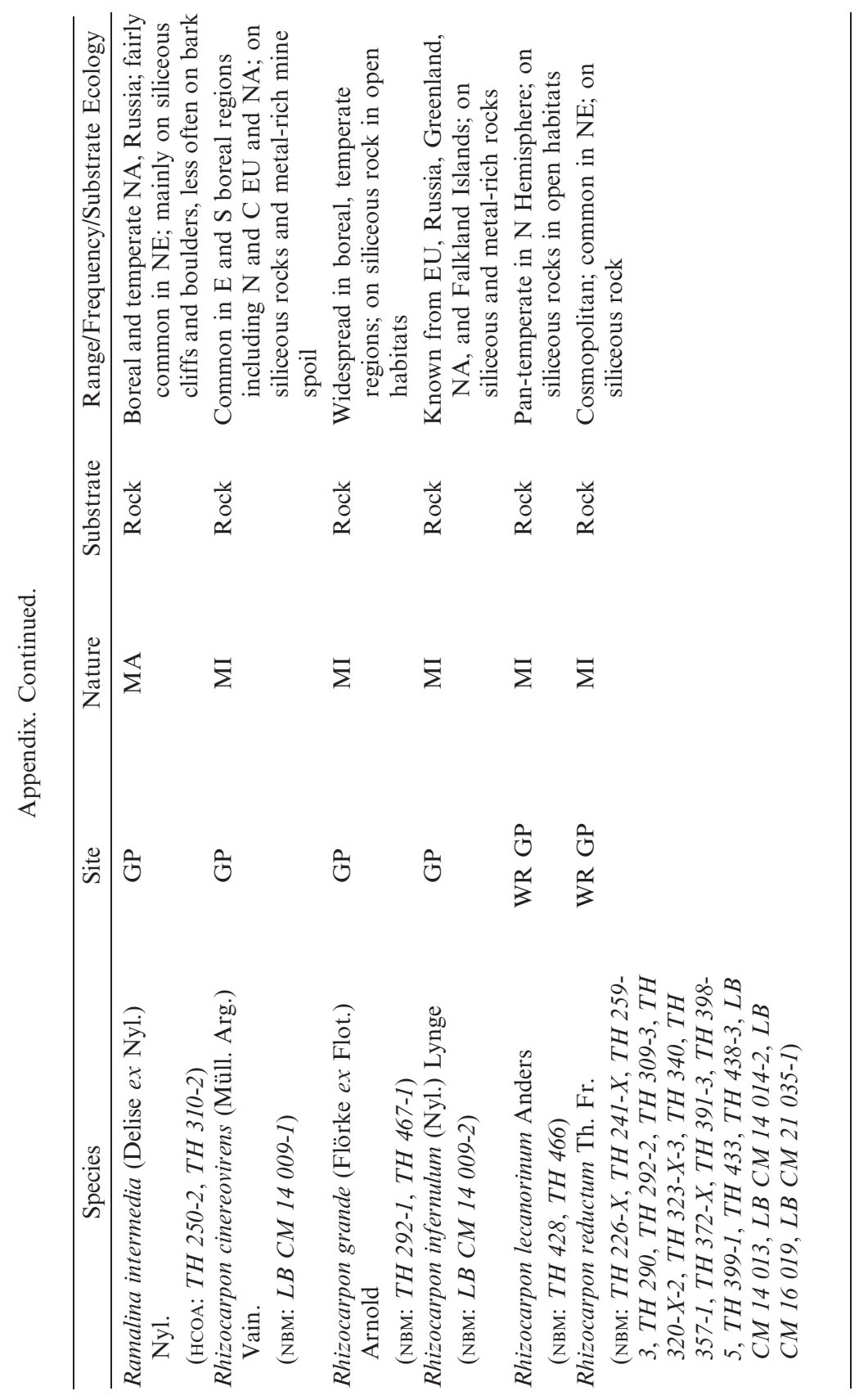




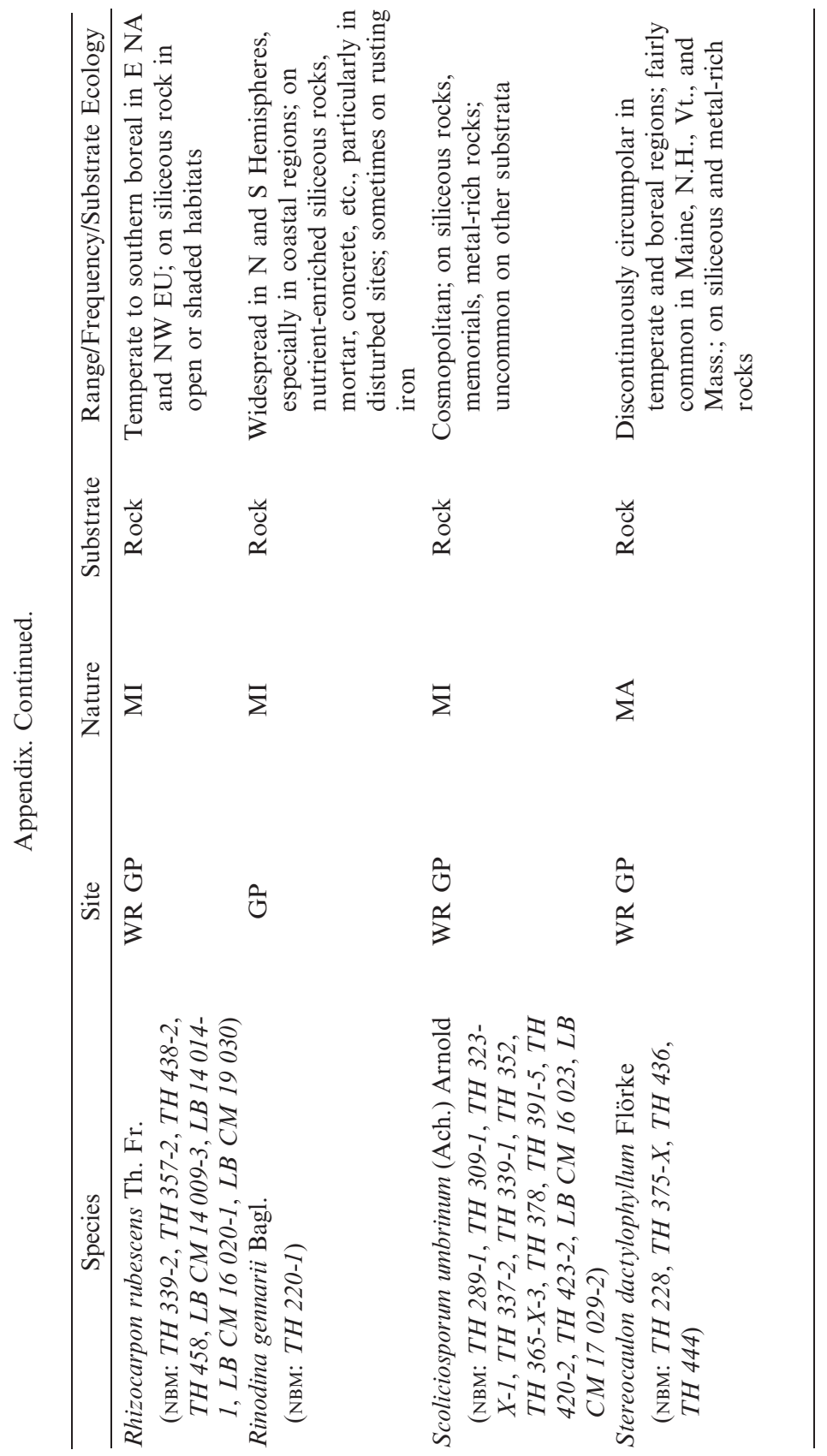




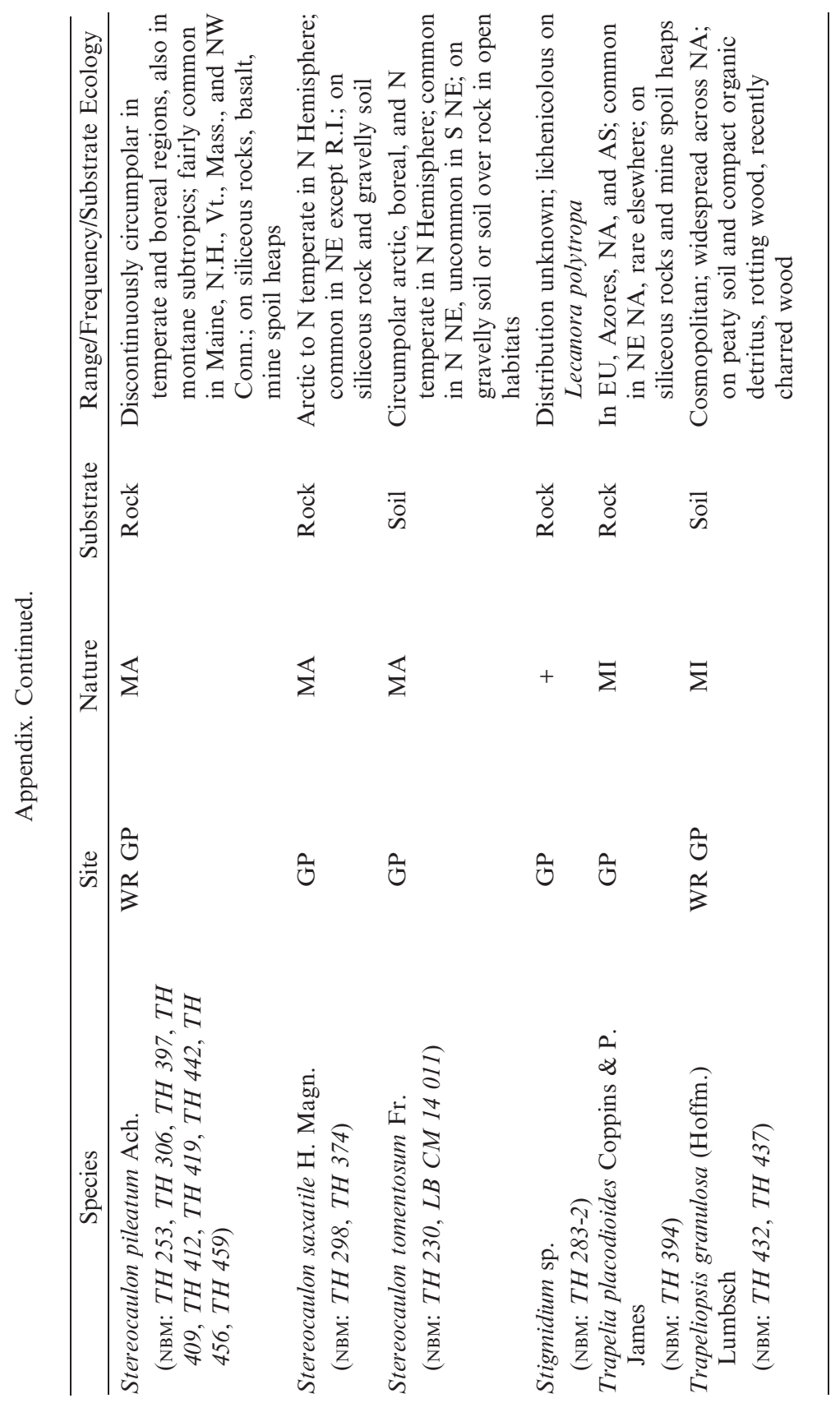




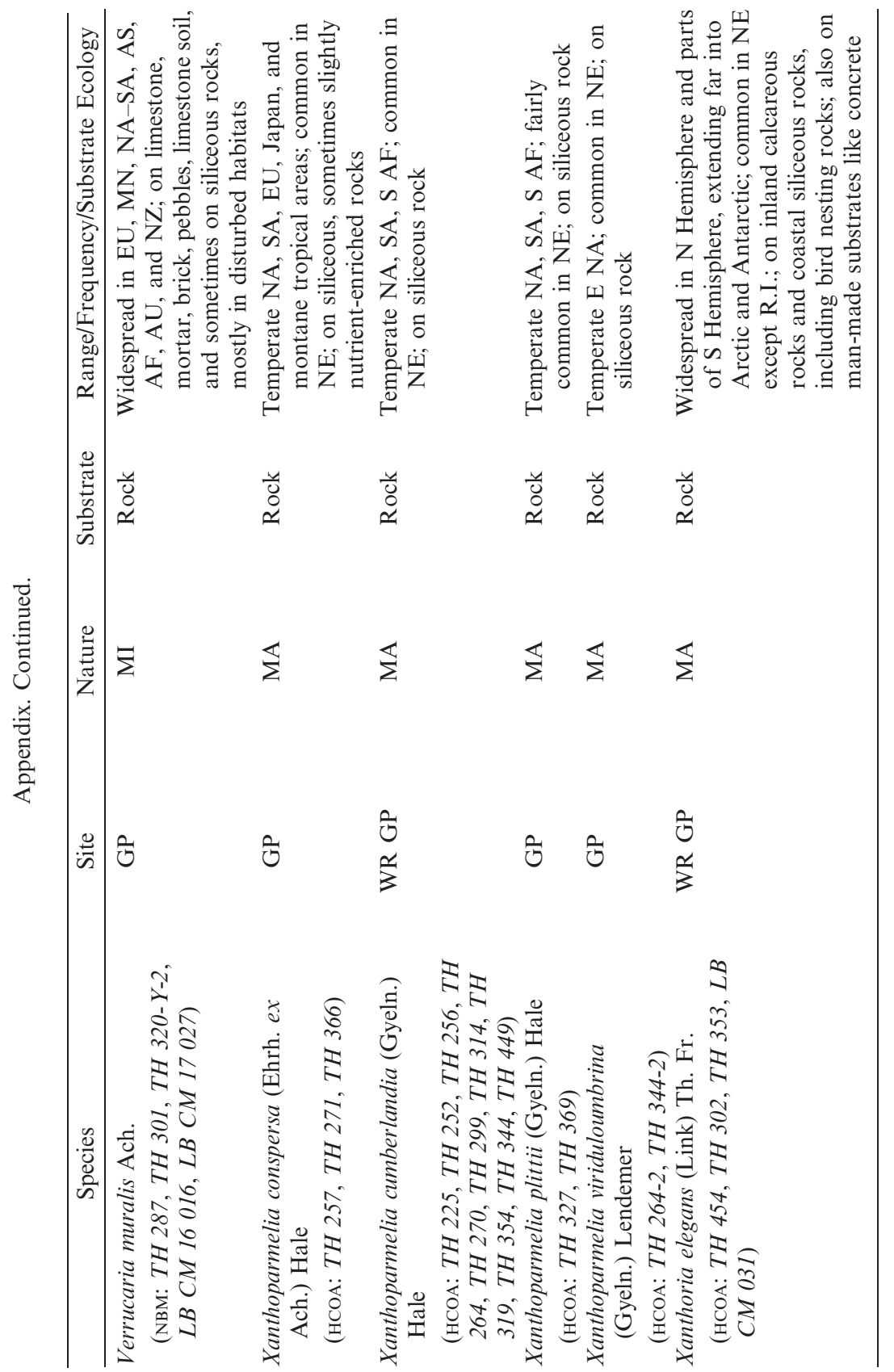




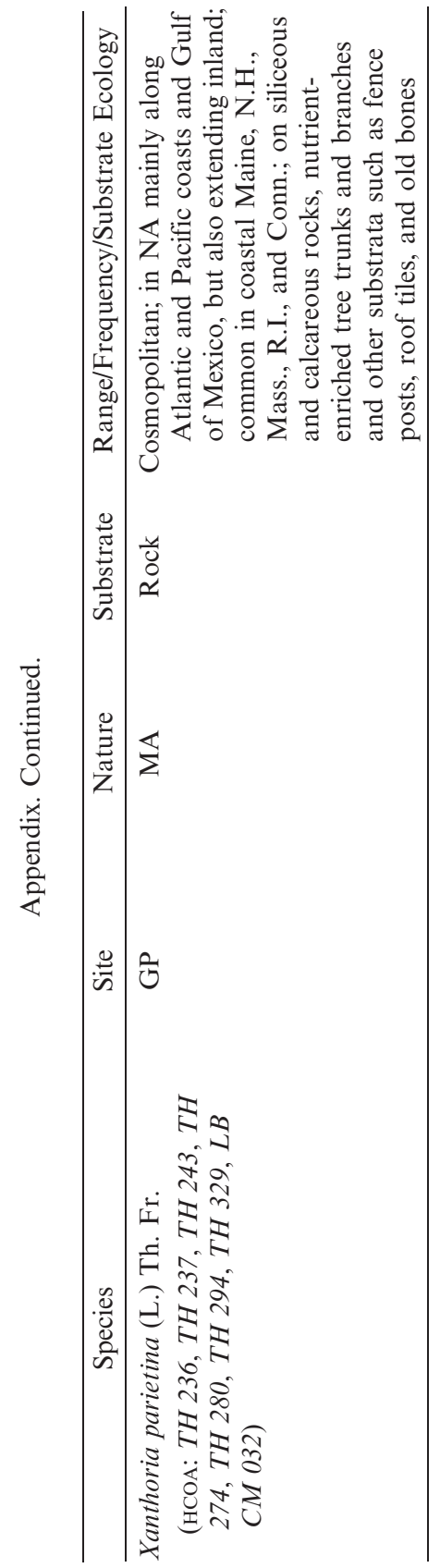

